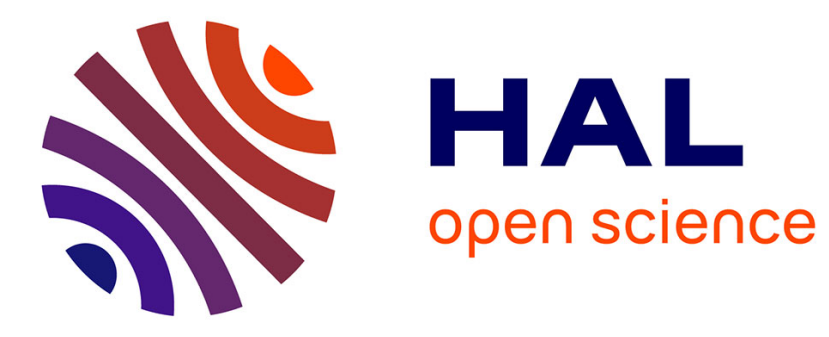

\title{
Site-Specific Dual Labeling of Proteins on Cysteine Residues with Chlorotetrazines
}

Coline Canovas, Mathieu Moreau, Claire Bernhard, Alexandra Oudot, Mélanie Guillemin, Franck Denat, Victor Goncalves

\section{- To cite this version:}

Coline Canovas, Mathieu Moreau, Claire Bernhard, Alexandra Oudot, Mélanie Guillemin, et al.. SiteSpecific Dual Labeling of Proteins on Cysteine Residues with Chlorotetrazines. Angewandte Chemie International Edition, 2018, 57 (33), pp.10646 - 10650. 10.1002/anie.201806053 . hal-01857108

\section{HAL Id: hal-01857108 \\ https://u-bourgogne.hal.science/hal-01857108}

Submitted on 8 Dec 2021

HAL is a multi-disciplinary open access archive for the deposit and dissemination of scientific research documents, whether they are published or not. The documents may come from teaching and research institutions in France or abroad, or from public or private research centers.
L'archive ouverte pluridisciplinaire HAL, est destinée au dépôt et à la diffusion de documents scientifiques de niveau recherche, publiés ou non, émanant des établissements d'enseignement et de recherche français ou étrangers, des laboratoires publics ou privés. 


\title{
Site-Specific Dual-Labeling of Proteins on Cysteine Residues with Chlorotetrazines
}

\author{
Coline Canovas, ${ }^{[a]}$ Mathieu Moreau, ${ }^{[a]}$ Claire Bernhard, ${ }^{[a]}$ Alexandra Oudot, ${ }^{[b]}$ Mélanie Guillemin, ${ }^{[b]}$ \\ Franck Denat, ${ }^{[a]}$ and Victor Goncalves *[a]
}

\begin{abstract}
Dual-labeled biomolecules constitute a new generation of bioconjugates with promising applications in therapy and diagnosis. Unfortunately, the development of these new families of biologics is hampered by the technical difficulties associated with their construction. In particular, the site-specificity of the conjugation is critical as the number and position of payloads can have a dramatic impact on the pharmacokinetic of the bioconjugate. Here, we introduce dichlorotetrazine as a trivalent platform for the selective double-modification of proteins on cysteine residues. This strategy is applied to the dual-labeling of albumin with a macrocyclic chelator for nuclear imaging and a fluorescent probe for fluorescence imaging.
\end{abstract}

Protein conjugates have become essential tools in chemical biology and human medicine. They are used daily as probes to explore cell biology, and as diagnostic agents in nuclear medicine departments. ${ }^{[1]}$ Similarly, antibody-drug conjugates (ADC) show impressive results in clinic and constitute an active field of research in pharmaceutical industry. ${ }^{[2]}$

Recent advances in protein (bio)-chemistry have made possible the production of dual-labeled proteins. ${ }^{[3]}$ While these molecules are more difficult to synthesize, they open up a world of new opportunities. Among them, Boerman and co-workers reported the development of bimodal imaging agents that allow the diagnosis of patients by whole body nuclear imaging and facilitate the work of the surgeon by providing fluorescence images within the intraoperative field. ${ }^{[4]}$ Likewise, Maruani and coworkers labeled an antibody with a cytotoxic drug and a fluorophore, thereby obtaining an ADC with theranostic potential. ${ }^{[3]}$ Another example is the development of heterobivalent agents for imaging or therapy, that target two receptors present at the surface of a specific cell to further enhance cell-selectivity and drug uptake. ${ }^{[5]}$

In all these cases, a careful control of the conjugation site on the protein is critical. Indeed, it has been shown that both the number and the localization of probes/drugs attached to an antibody have a dramatic impact on its biodistribution and the resulting image quality / therapeutic activity. ${ }^{[6]}$ Moreover, random labeling of proteins can affect negatively the scale-up and reproducibility of the production process and complicate drug approval by regulatory agencies. ${ }^{[2 b, 7]}$

Common approaches to achieve such site-specific labeling of proteins rely on the genetic engineering of recombinant proteins ${ }^{[8]}$ enzymatic modifications, ${ }^{[9]}$ the chemical targeting of

[a] C. Canovas, Dr. M. Moreau, Dr. C. Bernhard, Pr. F. Denat, Dr. V. Goncalves

Institut de Chimie Moléculaire de l'Université de Bourgogne, UMR6302, CNRS, Université Bourgogne Franche-Comté,

9 avenue Alain Savary, 21000, Dijon (France)

E-mail: victor.goncalves@u-bourgogne.fr

[b] Dr. A. Oudot, M. Guillemin

Georges-Francois LECLERC Cancer Center - UNICANCER

1 rue Pr Marion, 21079, Dijon (France)

Supporting information for this article is given via a link at the end of the document. rare amino acids ${ }^{[10]}$ or the introduction of non-canonical amino acids with bioorthogonally reactive side chains. ${ }^{[11]}$ Performing the site-specific modification of two amino acids on a protein is feasible, but requires complex protein engineering, which is difficult to transpose to large scale production. ${ }^{[12]}$

Consequently, future developments in this field will depend on our ability to identify labeling procedures that should ideally be: easy to perform (i.e. do not require advanced organic chemistry and/or molecular biology skills), site-specific (in order to facilitate the reproducibility and scale-up), tolerant (i.e. that can be performed under mild conditions with fragile molecules such as proteins) and modular (so that bioconjugates can be easily tailored to one's needs).

Here, we describe how dichloro-1,2,4,5-tetrazine, once monosubstituted with mercapto derivatives, can react selectively, within minutes and under mild conditions, with protein thiols through a nucleophilic aromatic substitution reaction. The resulting disubstituted tetrazine can further react with strained alkynes and alkenes to form site-specifically dual-labeled proteins (Figure 1). This strategy is exemplified with the dual-labeling of albumin for nuclear and fluorescence imaging.
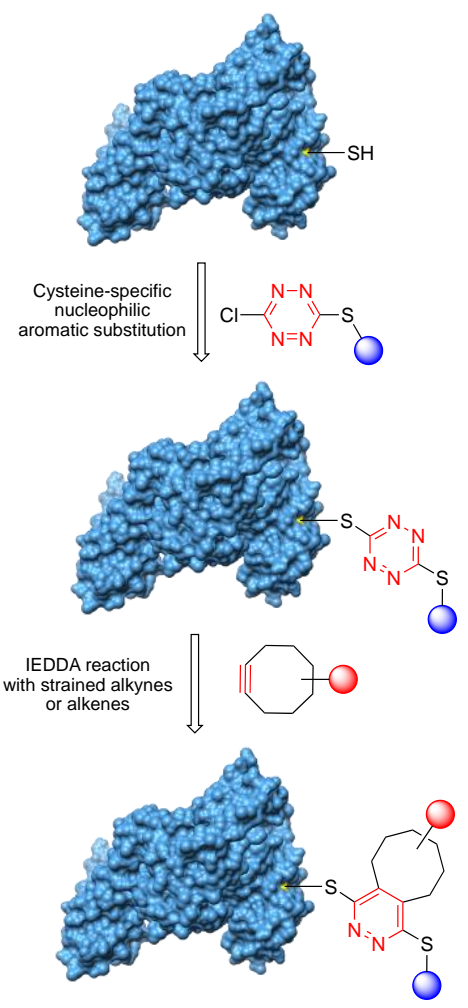

Figure 1. General methodology for the dual-labeling of proteins on cysteine residues with chlorotetrazines.

Reactivity of monosubstituted chlorotetrazines with model peptides.

Several groups reported that dichloro-1,2,4,5-tetrazine can undergo two successive nucleophilic aromatic substitutions by a 
variety of nucleophiles such as amines, thiols and alcohols, to form doubly substituted $s$-tetrazines. ${ }^{[13]}$ In particular, Hotha and co-workers showed that peracetylated sugar derivatives and protected tripeptides can react with dichlorotetrazine to form binary sugar-peptide conjugates. ${ }^{[14]}$ This chemistry has also elegantly been applied to the reversible stapling of peptides and proteins, through the incorporation of the tetrazine ring within a bisthiolate peptide motif. ${ }^{[15]}$ On these grounds, we investigated whether dichlorotetrazine could be used for the labeling of proteins, in mild and aqueous conditions, and whether its reactivity could be tuned to achieve the specific labeling of protein's solvent-exposed cysteines.

First, dichlorotetrazine was substituted with the commercially available amine-functionalized metal chelator (R)NODAGA-NH $\mathrm{N}_{2}$ (Scheme 1). This polyazamacrocycle derivative has been shown to form particularly stable complexes with radioactive metals such as gallium-68 and copper-64, used in positron emission tomography (PET). ${ }^{16]}$ The reaction proceeded easily in borate buffer at $\mathrm{pH} 8.0$ and at room temperature to give the derivative (R)-NODAGA-NH-Tz-Cl 1. Similarly, monosubstituted chlorotetrazines could be obtained through the reaction of dichlorotetrazine with thiol nucleophiles. Three mercapto-substituted chlorotetrazines, including (R)-NODAGA and DOTAGA metal chelators and a fluorescent probe (2-4), were thus obtained in moderate to good yields.

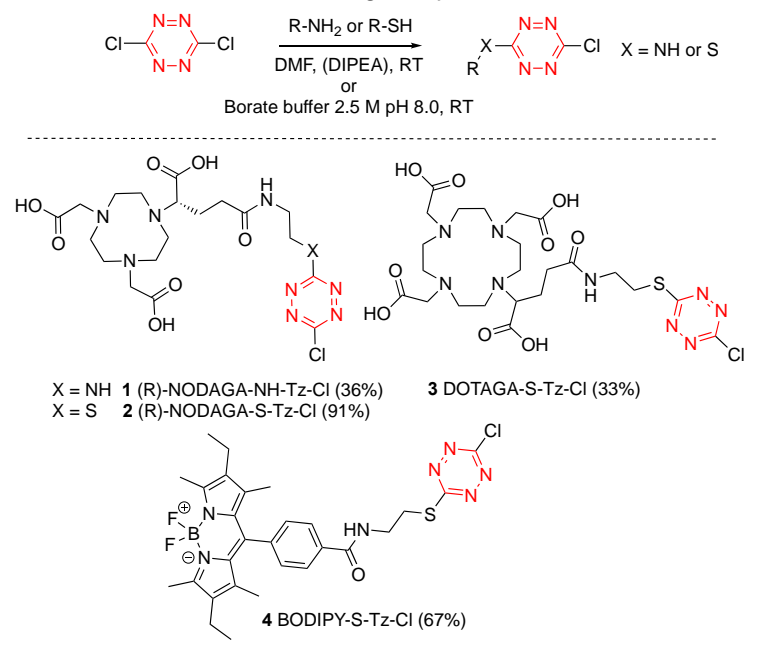

Scheme 1. Monosubstitution of dichlorotetrazine with amine and thio nucleophiles.

Then, two model peptides, Ac-CKYWGRGDS-NH $\mathbf{5}$ and Ac-MKYWGRGDS-NH $\mathrm{N}_{2}$ 6, were synthesized. These peptides, which have been previously described by Popik and co-workers, contain all common nucleophilic amino acids. ${ }^{[17]}$ They differ by the presence of a $\mathrm{N}$-terminal cysteine in $\mathbf{5}$, which is replaced by a methionine in $\mathbf{6}$. Cysteines are rare amino acids in proteins, that can be introduced by well-established procedures. ${ }^{[18]}$ Due to the strong nucleophilicity of the thiol side chain and its low $\mathrm{pKa}$, reaction of cysteines with electrophiles is often highly selective. On this basis, we investigated whether the chlorine atom of monosubstituted chlorotetrazines could react with protein's amine and/or thiol side chain functions, under mild conditions.

In preliminary experiments, the monosubsituted $(R)$ NODAGA-NH-Tz-Cl 1 failed to react with both peptides below $50^{\circ} \mathrm{C}$. Conjugation could be achieved at higher temperatures with peptide $5\left(>80^{\circ} \mathrm{C}\right)$, but initiated the formation of significant amounts of unidentified degradation products.

Subsequently, similar experiments were carried out with the more electron-deficient thioether derivative (R)-NODAGA-S-Tz-Cl
2. The first reactions were performed in phosphate buffer at near neutral $\mathrm{pH}(\mathrm{pH} 7.13)$ in the presence of $20 \mu \mathrm{M}$ of peptide, a concentration commonly used for the labeling of proteins (Figure 2). In these conditions, 2 reacted with the peptide 5 rapidly, with full conversion achieved in less than $1 \mathrm{~min}$ of incubation at room temperature, to give the conjugate 7 , while 6 failed to react.

Figure 2. The monosubstituted chlorotetrazine 2 reacts selectively with the Peptide 5
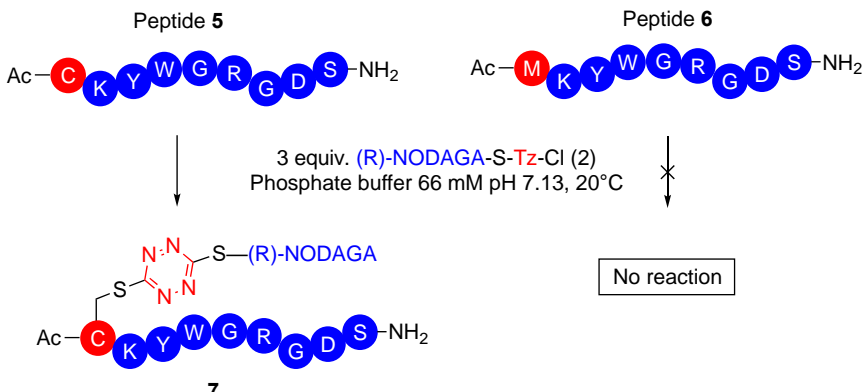

cysteine residue of the model peptide $\mathbf{5}$, under mild conditions, to give a doubly substituted tetrazine.

Since the kinetics of reaction of protein's thiols/amines with electrophilic species is known to be $\mathrm{pH}$-dependent, the reaction was repeated at various $\mathrm{pH}$ (Figure 3 ). As expected, the reaction rate of peptide $\mathbf{5}$ with $\mathbf{2}$ decreased in more acidic conditions, but still reached completion after $30 \mathrm{~min}$, even at $\mathrm{pH} 3.35$. More importantly, despite the presence of multiple nucleophiles in the peptide sequence, the sole product detected was the monoconjugated product 7 . In the presence of a large excess (25 equivalents) of reactive probe 2 , some labeling of the lysine residues could be detected at $\mathrm{pH} 7.13(14 \%$ after $3 \mathrm{~h}$ of incubation; Figure S1 supplementary information). However, the selectivity could be easily restored by slightly increasing the acidity of the solution ( $<2 \%$ Lys-labeling at $\mathrm{pH} 5.15$ ).

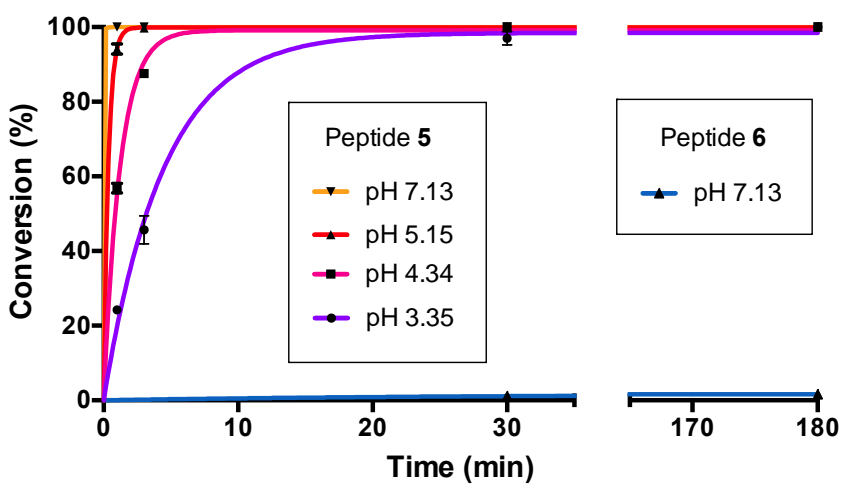

Figure 3. Conversion of peptides 5 and 6 in the presence of 2.5 equivalents of (R)-NODAGA-S-Tz-Cl 2 by RP-HPLC-MS (integration at $214 \mathrm{~nm}$ ). Reactions were performed in acetate $(110 \mathrm{mM})$ or phosphate $(66 \mathrm{mM})$ buffer at $20^{\circ} \mathrm{C}$ at the indicated $\mathrm{pH}$.

These preliminary results, which demonstrate the excellent selectivity of chlorotetrazine (substituted with a thioether derivative) for cysteine residues, prompted us to evaluate this platform on a more relevant protein model.

Cysteine-specific double-labeling of serum albumin with the metal chelator (R)-NODAGA and the fluorescent dye sulfoCy5

Serum albumin is the most abundant blood plasma protein. It is characterized by a particularly long half-life in blood $(\sim 19$ days 
in humans) and an ability to accumulate in solid tumor by the "enhanced permeability and retention" (EPR) effect. ${ }^{[19]}$ As a result, this small globular protein has been extensively used as a versatile carrier for drug delivery, and albumin-conjugated probes have been applied to the visualization of blood pool and the detection of lymphatic sentinel nodes, in preclinical settings, by nuclear imaging (SPECT and PET), magnetic resonance imaging (MRI), and optical imaging. ${ }^{[20]}$

Among the 35 cysteines present in human serum albumin, most are involved in the formation of structural disulfides, and only one, $\mathrm{Cys}^{34}$, is (mainly) present in its reduced form. ${ }^{[21]}$ On this basis, we undertook the evaluation of the tetrazine platform for the cysteine-specific labeling of bovine serum albumin (BSA). A preliminary Ellman assay revealed that the albumin used in this study contained 0.5 reactive sulfhydryl group per molecule of BSA, in good agreement with data from literature (Supplementary information). ${ }^{[22]}$

BSA $(1.0 \mathrm{mg} / \mathrm{mL})$ was first incubated with 10 equivalents of

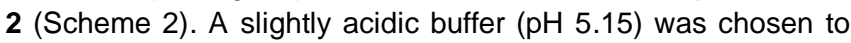
favor the selective labeling of thiols (Figure 4).

$$
10 \text { equiv. (R)-NODAGA-S-Tz-Cl (2) }
$$

BSA-SH $\stackrel{\mathrm{AcONH}_{4} \text { buffer pH 5.15, 1 h, RT }}{\longrightarrow}$ BSA-S-Tz-S-(R)-NODAGA 8

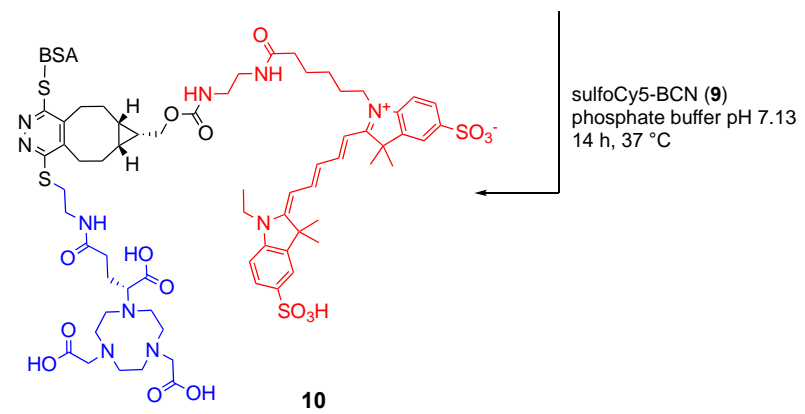

Scheme 2. Sequential dual-labeling of BSA

After $1 \mathrm{~h}$ at room temperature, the excess of probe 2 was removed by ultrafiltration and a RP-HPLC-MS analysis of the solution confirmed the sole formation of the expected product 8 (Figure 4).
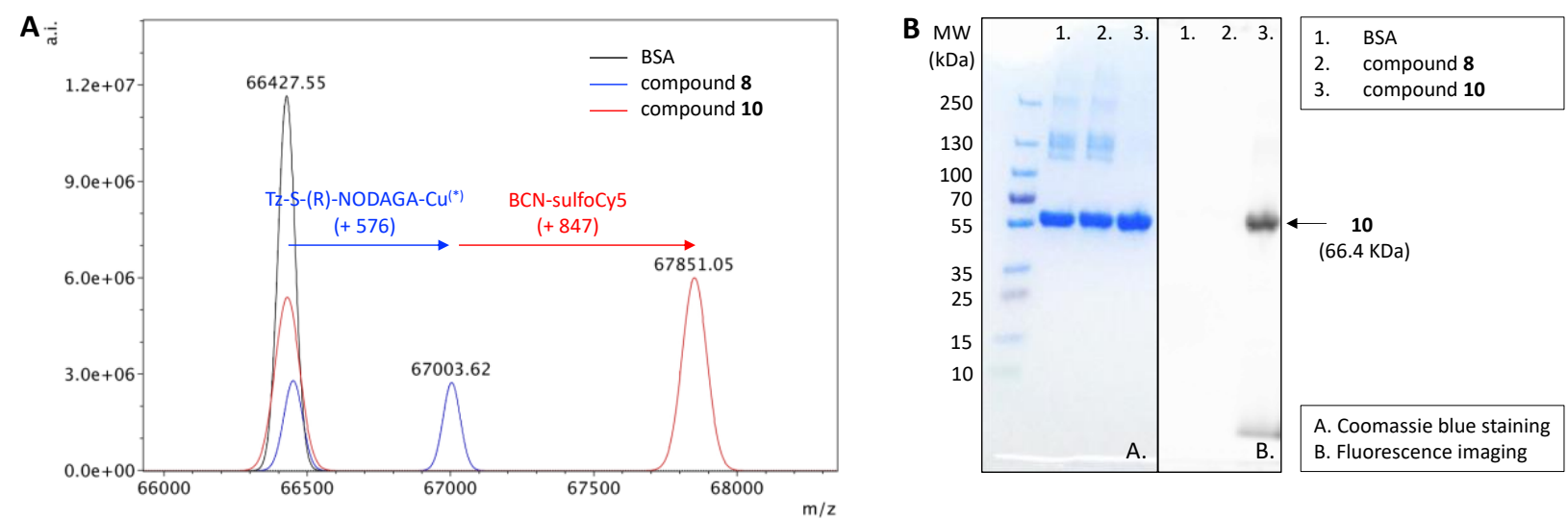

Figure 4. (A) Deconvoluted ESI-MS spectra of BSA, 8 and 10. (*) The copper adduct is formed during ESI-MS analysis. (B) SDS-PAGE analysis of BSA, 9 and 10 after Coomassie blue staining and by fluorescence (excitation at $620 \mathrm{~nm}$; emission at $670 \mathrm{~nm}$ ). 1,2,4,5-tetrazines are usually excellent partners for inverse electron demand Diels-Alder reactions with a variety of dienophiles and, in particular, strained alkynes and alkenes. ${ }^{[23]}$ Thus, a disulfonated cyanine 5 fluorophore, suitable for nearinfrared imaging, was conjugated to a bicyclo[6.1.0]nonyne moiety to give the "clickable" probe sulfoCy5-BCN 9 (supplementary information). 9 (10 equivalents) was then incubated in the presence of 8 in phosphate buffer at pH 7.13.

Although the substitution of dichlorotetrazine with thioalkyl groups reduced its reactivity, the IEDDA reaction was completed over $12 \mathrm{~h}$ in mild conditions $\left(37^{\circ} \mathrm{C}\right)$ to afford the site-specifically doubly-labeled protein 10 . The conjugate was purified by size exclusion chromatography and isolated with a protein recovery yield of $68 \%$.

The stability of the resulting bimodal imaging agent was evaluated in human plasma, at $37^{\circ} \mathrm{C}$, by gel electrophoresis (SDS-PAGE; Supplementary information). No release of the fluorescent dye could be observed over $48 \mathrm{~h}$, suggesting a good stability of the ternary platform in vitro.

Subsequently, the bioconjugate $\mathbf{1 0}$ was evaluated in vivo on balb/c nude mice xenografted with BT-474 human mammary tumor cells. The compound was injected intravenously $(1.35 \mathrm{nmol} / \mathrm{mouse})$ through a lateral tail vein and its biodistribution was monitored by fluorescence imaging at $620 / 670 \mathrm{~nm}$ over $24 \mathrm{~h}$ (Figure 5A). Most of the fluorescence signal localized in the tumor region at $1 \mathrm{~h}$ post injection (p.i.), with the signal further increasing over time till $24 \mathrm{~h}$ p.i. The mice were then euthanized and the fluorescence signal was measured ex-vivo on isolated organs (Figure 5B). These data confirmed the results observed previously, with a major uptake of the bioconjugate in the tumor mass, probably through the EPR effect. Fluorescence signal could also be detected in organs involved in the clearance pathways of the imaging agent (liver, spleen, kidneys, bladder) as well as in blood and muscle, as a result of the long circulating halflife of albumin derivatives. 

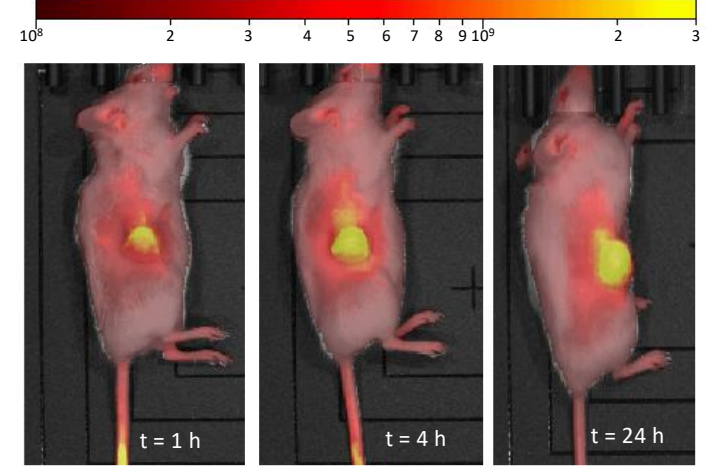

B

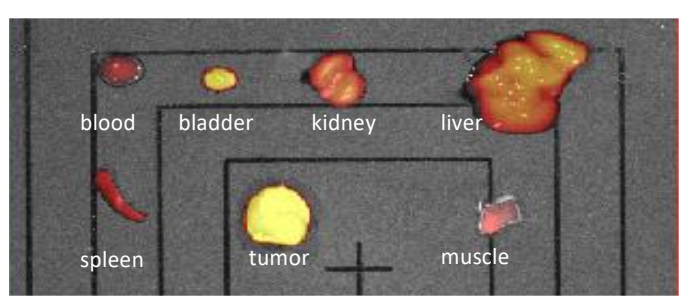

Figure 5. Illustrative images of the biodistribution of the bioconjugate $\mathbf{1 0}$ by fluorescence imaging (excitation at $620 \mathrm{~nm}$ and emission at $670 \mathrm{~nm}$ ) (A) in a living mouse at $1 \mathrm{~h}, 4 \mathrm{~h}$ and $24 \mathrm{~h}$ post injection (p.i.) and, (B) ex-vivo on isolated organs at $24 \mathrm{~h}$ p.i. Fluorescence signal, displayed as radiant efficiency, is superimposed to white light images. Quantification of the signal is available in the supplementary information document

In summary, 3,6-dichlorotetrazine constitutes a promising platform for the assembly of doubly-modified proteins. In particular, the introduction, in the first step, of a thiol derivative gives access to monosubstituted chlorotetrazines that display excellent selectivity for cysteine residues in proteins. The tetrazine ring can then further react with strained dienophiles to give site-specifically doubly-modified proteins in mild conditions. Owing to its simplicity, this straightforward two-step procedure should facilitate the production of a new generation of bioconjugates. This technology was exemplified in this paper with the preparation of an albumin derivative suitable for multimodal imaging in vivo. Although proteins that contain reactive cysteine residues in their sequence are rare, one can easily introduce such canonical amino acid in a protein of interest by genetic engineering (e.g. THIOMAB antibody). ${ }^{[24]}$ Ongoing efforts focus on the application of this versatile technology to the preparation of theranostic agents.

\section{Acknowledgements}

This work was performed within Pharm'image, a regional center of excellence in Pharmaco-imaging. Financial support was provided by the French Government through the French National Research Agency (ANR) under the programs "Investissements d'Avenir" (IMAPPI Equipex) and "AAP Générique 2017" (project ZINELABEL), the CNRS, the "Université de Bourgogne" and the "Conseil Régional de Bourgogne" through the 3MIM program. This work is also part of the project "Pharmaco-imagerie et agents théranostiques" supported by the Conseil Régional de Bourgogne Franche-Comté through the «Plan d'Action Régional pour I'Innovation » (PARI) and by the European Union through the PO FEDER-FSE 2014/2020 Bourgogne program. We thank M.-J. Penouilh for assistance in obtaining mass spectra, as well as Pr. A. Romieu and Dr. C. Goze for kindly giving us fluorescent probes and Dr. F. Boschetti (CheMatech) for providing the polyazamacrocycles.

Keywords: Bioconjugation • Click chemistry • Cysteine $•$ Protein engineering $\cdot$ Site-specific

[1] M. L. James, S. S. Gambhir, Physiol. Rev. 2012, 92, 897-965.

[2] a) A. Thomas, B. A. Teicher, R. Hassan, The Lancet. Oncology 2016, 17, e254-262; b) A. Mullard, Nat. Rev. Drug Discov. 2013, 12, 329-332.

[3] A. Maruani, D. A. Richards, V. Chudasama, Org. Biomol. Chem. 2016, 14, 6165-6178.

[4] a) S. Lutje, M. Rijpkema, W. Helfrich, W. J. Oyen, O. C. Boerman, Mol. Imaging Biol. 2014, 16, 747-755; b) M. C. Hekman, O. C. Boerman, M. de Weijert, D. L. Bos, E. Oosterwijk, H. F. Langenhuijsen, P. F. Mulders, M. Rijpkema, Clin. Cancer Res. 2016, 22, 4634-4642.

[5] L. P. Xu, J. S. Josan, J. Vagner, M. R. Caplan, V. J. Hruby, E. A. Mash, R. M. Lynch, D. L. Morse, R. J. Gillies, P. Natl. Acad. Sci. U.S.A. 2012, 109, 21295-21300.

[6] a) A. Perols, H. Honarvar, J. Strand, R. Selvaraju, A. Orlova, A. E. Karlstrom, V. Tolmachev, Bioconjug. Chem. 2012, 23, 1661-1670; b) M. Rijpkema, D. L. Bos, A. S. Cornelissen, G. M. Franssen, D. M. Goldenberg, W. J. Oyen, O. C. Boerman, Mol. Imaging 2015, 14, 348355.

[7] I. Sassoon, V. Blanc, Methods Mol Biol 2013, 1045, 1-27.

[8] R. Y. Tsien, Angew. Chem. Int. Ed. 2009, 48, 5612-5626.

[9] M. Rashidian, J. K. Dozier, M. D. Distefano, Bioconjug. Chem. 2013, 24, 1277-1294.

[10] O. Boutureira, G. J. Bernardes, Chem. Rev. 2015, 115, 2174-2195.

[11] K. Lang, J. W. Chin, Chem. Rev. 2014, 114, 4764-4806.

[12] A. Sachdeva, K. Wang, T. Elliott, J. W. Chin, J. Am. Chem. Soc. 2014, 136, 7785-7788.

[13] a) Y. H. Gong, P. Audebert, J. Tang, F. Miomandre, G. Clavier, S. Badre, R. Meallet-Renault, J. Marrot, J. Electroanal. Chem. 2006, 592, 147-152; b) Z. Novak, B. Bostai, M. Csekei, K. Lorincz, A. Kotschy, Heterocycles 2003, 60, 2653-2668; c) S. Pluczyk, P. Zassowski, L. Galmiche, P. Audebert, M. Lapkowski, Electrochim. Acta 2016, 212, 856-863; d) D. Andrade-Acuna, J. G. Santos, W. Tiznado, A. Canete, M. E. Aliaga, J. Phys. Org. Chem. 2014, 27, 670-675.

[14] B. Venkateswara Rao, S. Dhokale, P. R. Rajamohanan, S. Hotha, Chem. Commun. (Camb.) 2013, 49, 10808-10810.

[15] a) S. P. Brown, A. B. Smith, 3rd, J. Am. Chem. Soc. 2015, 137, 40344037; b) M. J. Tucker, J. R. Courter, J. Chen, O. Atasoylu, A. B. Smith, 3rd, R. M. Hochstrasser, Angew. Chem. Int. Ed. Engl. 2010, 49, 36123616.

[16] E. Gourni, C. Canovas, V. Goncalves, F. Denat, P. T. Meyer, H. R. Maecke, PLoS One 2015, 10, e0145755.

[17] S. Arumugam, J. Guo, N. E. Mbua, F. Friscourt, N. Lin, E. Nekongo, G. J. Boons, V. V. Popik, Chem. Sci. 2014, 5, 1591-1598.

[18] a) M. E. B. Smith, F. F. Schumacher, C. P. Ryan, L. M. Tedaldi, D. Papaioannou, G. Waksman, S. Caddick, J. R. Baker, J. Am. Chem. Soc. 2010, 132, 1960-1965; b) A. Lyons, D. J. King, R. J. Owens, G. T. Yarranton, A. Millican, N. R. Whittle, J. R. Adair, Protein Eng. 1990, 3, 703-708.

[19] a) M. T. Larsen, M. Kuhlmann, M. L. Hvam, K. A. Howard, Mol. Cell Ther. 2016, 4, 3; b) F. Kratz, B. Elsadek, J. Control. Release 2012, 161, 429445.

[20] W. Cao, X. Lu, Z. Cheng, Curr. Pharm. Des. 2015, 21, 1908-1915.

[21] A. J. Lepedda, A. Zinellu, G. Nieddu, P. De Muro, C. Carru, R. Spirito, A. Guarino, F. Piredda, M. Formato, Oxid. Med. Cell Longev. 2014, 2014, 690953.

[22] W. E. Funk, H. Li, A. T. lavarone, E. R. Williams, J. Riby, S. M. Rappaport, Anal. Biochem. 2010, 400, 61-68.

[23] a) D. L. Boger, R. P. Schaum, R. M. Garbaccio, J. Org. Chem. 1998, 63, 6329-6337; b) A. Hamasaki, R. Ducray, D. L. Boger, J. Org. Chem. 2006, 71, 185-193; c) B. L. Oliveira, Z. Guo, G. J. L. Bernardes, Chem. Soc. Rev. 2017, 46, 4895-4950.

[24] J. R. Junutula, H. Raab, S. Clark, S. Bhakta, D. D. Leipold, S. Weir, Y. Chen, M. Simpson, S. P. Tsai, M. S. Dennis, Y. Lu, Y. G. Meng, C. Ng, J. Yang, C. C. Lee, E. Duenas, J. Gorrell, V. Katta, A. Kim, K. McDorman, K. Flagella, R. Venook, S. Ross, S. D. Spencer, W. Lee Wong, H. B. 
Lowman, R. Vandlen, M. X. Sliwkowski, R. H. Scheller, P. Polakis, W. Mallet, Nat. Biotechnol. 2008, 26, 925-932. 
